\title{
Hubungan Antara Harga Diri Dan Konsep Diri Dengan Prestasi Belajar Bahasa Inggris Mahasiswa Prodi DIII Keperawatan Tahun Ajaran 2017-2018
}

\author{
Sylene Meilita Ayu \\ Akademi Kesehatan Rustida \\ sylenemeilitaayu@yahoo.co.id \\ Siswoto Hadi Prayitno \\ Akademi Kesehatan Rustida \\ siswotohp@gmail.com
}

\begin{abstract}
Abstrak
Prestasi belajar memberikan kepuasan pribadi, popularitas serta menimbulkan harga diri tinggi dalam pandangan orang lain. Harga diri tinggi bagi mahasiswa membuat cara berpikir lebih kreatif sehingga dapat berpengaruh pada perilaku positif karena ada perasaan diterima, sebaliknya bila mahasiswa memiliki harga diri rendah maka prestasi belajar kurang memuaskan. Sedangkan prestasi belajar juga dipengaruhi oleh konsep diri. Penelitian ini merupakan penelitian kuantitatif non-eksperimental jenis deskriptif korelasional. Populasi penelitian ini adalah mahasiswa semester dua Prodi D III Keperawatan, dengan sampel sebanyak 45 mahasiswa. Tujuan penelitian ini mengetahui hubungan konsep diri dan harga diri dengan prestasi belajar mata ajar Bahasa Inggris. Data diperoleh menggunakan kuesioner. Penelitian ini menggunakan analisis regresi linier berganda. Hasil analisis didapatkan Adjusted $\mathrm{R}$ square $=0.094$ yang berarti pengaruh konsep diri dan harga diri terhadap prestasi belajar sebesar $9.4 \%$ sedangkan $90.6 \%$ dipengaruhi faktor lain.
\end{abstract}

Kata Kunci: harga diri, konsep diri, prestasi belajar Bahasa Inggris

\section{Pendahuluan}

Proses belajar bagi individu merupakan hal yang sangat penting, melalui belajar individu dapat mengenal lingkungannya dan dapat menyesuaiakn diri dengan lingkungannya. Individu yang belajar maka harus menghasilkan perubahan dalam dirinya. Seberapa jauh hasil belajar telah dicapai maka harus dilakukan evaluasi (Naike, 2017). Evaluasi hasil belajar mahasiswa dilakukan untuk mengetahui seberapa jauh mahasiswa telah mencapai sasaran belajar atau disebut dengan prestasi belajar (Risa Paskahandriati, 2010). Prestasi belajar 
merupakan ukuran keberhasilan mahasiswa dalam jenjang pendidikannya. Paradigma pembelajaran terutama Bahasa Inggris harus berdampak positif bagi mahasiswa dengan menggali sumber positif yang ada di lingkungan belajar termasuk dukungan sosial (Woro Kusrini, 2014).

Lingkungan berpengaruh dalam belajar Bahasa Inggris, selain dalam belajar Bahasa Inggris mahasiswa harus mencari stimulasi dan input dari orang lain (Budiawan, 2008). Belajar Bahasa Inggris mensyaratkan usaha yang total, dosen dituntut mencari cara terbaik dalam mengajar. Pembelajaran aktif dimana mahasiswa dipandang sebagai subyek, namun keberhasilan pembelajaran banyak ditentukan oleh mahasiswa sendiri (Ratih, 2005). Demikian pula prestasi belajar yang diperoleh mahasiswa dapat meningkatkan harga diri yang biasanya diekspresikan dengan keyakinan untuk menjadi mampu penting dan berharga (Kamila, 2013). Widiarti, (2007) menyatakan harga diri tinggi dapat meningkatkan prestasi belajar. Harga diri tinggi bagi mahasiswa membuat cara berpikir lebih kreatif dan bersemangat sehingga dapat berpengaruh pada perilaku positif karena ada perasan diterima dan dihargai, sebaliknya bila mahasiswa memilki hargi diri rendah prestasi belajar kurang memuaskan (Margono, 2014). Sedangkan untuk prestasi belajar yang baik diperlukan adanya konsep diri (Sumantri, 2011), karena tercapinya prestasi belajar juga dipengaruhi oleh konesp diri (Liauwrencia, 2014). Sumantri, (2011) menyatakan bahwa prestasi belajar 67\% dipengaruhi oleh konsep diri.

Prestasi belajar yang baik dapat memberikan kepuasan pribadi dan popularitas serta dapat menimbulkan harga diri tinggi dalam pandangan orang lain (Margono, 2014). Neny Irawwati, (2012) menyatakan bahwa Indonesia menurut Human Development Report tahun 2004 menduduki posisi 111 dari 177 negara, dari hasil tersebut maka prestasi belajar menjadi hal penting untuk dikaji dan dievaluasi lebih mendalam, mengingat hal ini merupakan faktor penting untuk mengevalusi mutu pendidikan. Prestasi belajar menggambarkan kemampuan baik aspek pengetahuan, sikap dan ketrampilan yang dimiliki oleh mahasiswa, prestasi belajar yang baik akan dapat diperoleh jika individu memiliki harga diri yang positif terhadap kemampuan yang dimilikinya (Naike, 2017). Suatu interaksi yang 
persisten antara harga diri dan prestasi belajar dimana harga diri mempengaruhi prestasi belajar dan prestasi belajar mempengaruhi harga diri (Surani, 2013).

Pengaruh globalisasi di berbagai bidang kehidupan menuntut adanya inovasi dalam peningkatan kualitas sumberdaya manusia. Kualitas sumberdaya manusia perlu kiranya ditingkatkan dalam kemampuan Bahasa Inggris sebagai bahasa komunikasi dunia (Sutiyoso, 2010). Guna meningkatkan prestasi belajar Bahasa Inggris diperlukan dukungan, selain motivasi, minat, bakat dan kemampuan kognitif (Budiawan, 2008). Mata ajar Bahasa Inggris telah diajarkan mulai sekolah dasar sampai dengan perguruan tinggi namun faktanya belum yang seperti diharapkan, kemungkinan disebabkan metode pembelajaraan yang kurang tepat, kurang menarik, situasi belajar terlalu tegang sehingga berdampak pada minat belajar Bahasa Inggris mahasiswa menurun (Sutiyoso, 2010).

Langkah terbaik untuk meningkatkan prestasi belajar bagaimana pengajar mencipakan proses pembelajaran yang membuat mahasiswa senang, sikap humoris kreatif dan trampil perlu dilakukan oleh pengajar (Hermayawati, 2010). Pengajaran Bahasa Inggris harus berorientasi pada kebutuhan mahasiswa sehingga dosen harus mampu mengembangkan bahan ajar secara mandiri tidak hanya mengandalkan buku paket (Rizal, 2013). Pengajar yang menyampaikan pembelajaran yang menarik dapat menarik minat belajar mahasiswa yang pada akhinya meningkatkan prestasi belajar, prestasi yang baik dapat meningkatkan harga diri mahasiswa sebaliknya bila prestasi tidak baik dapat menurunkan harga diri mahasiswa (Dinda Ayu Noviariandani, 2012).

Dari berbagai macam masalah yang dapat berpengaruh pada harga diri maka peneliti tertarik meneliti hubungan harga diri dan konsep diri dengan prestasi belajar mata kuliah Bahasa Inggris mahasiswa semester II Prodi DIII Keperawatan Tahun Ajaran 2017-2018.

\section{Konsep Diri}

Konsep diri merupakan cara pandang individu mengenai dirinya baik fisik, emosi, intelektual social dan spiritual (Prabawati Setyo Pambudi, 2012) dan kepercayaan, yang diyakini individu yang dapat mempengaruhi proses interaksi social denga lingkungannya (Pambudi \& Wijayanti, 2011). 


\section{Harga Diri}

Harga diri merupakan evaluasi individu tentang dirinya terhadap hasil yang dicapai dengan menganalisis seberapa banyak kesesuaian tingkah laku dengan ideal dirinya (Surani, 2013).

\section{Prestasi Belajar}

Prestasi belajar merupakan suatu aktifitas mental atau psikis yang berlangsung dalam interaksi aktif dengan lingkungannya, menghasilkan perubahan dalam hal pengetahuan, pemahaman, keterampilan, nilai maupun sikap (Winkel,1989:53) Prestasi belajar. Surtinah Tirtinegoro (dalam Anne, 2011) menjelaskan bahwa prestasi belajar merupakan penilaian hasil usaha kegiatan belajar yang dinyatakan dalam simbol angka, huruf, maupun kalimat yang dapat mencerminkan hasil yang sudah dicapai oleh setiap anak didik dalam periode tertentu.

Dari teori di atas dapat ditarik kesimpulan bahwa prestasi belajar merupakan ukuran keberhasilan kegiatan belajar mahasiswa dalam menguasai sejumlah mata kuliah selama periode tertentu yang dinyatakan dalam bentuk nilai akhir, dimana nilai akhir tersebut mencerminkan keberhasilan peserta didik dalam kegiatan pembelajarannya.

Penilaian prestasi belajar mahasiswa sangat penting untuk mengetahui sejauh mana taraf pengetahuan dan kualitas prestasi mahasiswa selama mengikuti kegiatan belajar mengajar. Oleh karena itu yang dapat dilakukan pendidik adalah mengamati tingkah laku yang dianggap penting dan dapat mencerminkan perubahan yang terjadi sebagai hasil belajar peserta didik baik dari segi perubahan pengetahuan, sikap, maupun keterampilan. Dalam penelitian ini prestasi belajar yang dimaksut adalah hasil belajar mahasiswa yang diisyaratkan dengan angka yang diambil dari nilai Bahasa Inggris mahasiswa dalam Kartu Hasil Studi (KHS) semester genap 2017-2018.

Menurut Ahmadi (2004:138) prestasi belajar yang dicapai seseorang merupakan hasil interaksi berbagai faktor yang mempengaruhi baik dari dalam diri (faktor internal) maupun faktor luar (faktor eksternal) individu. Pengenalan 
terhadap faktor - faktor yang mempengaruhi prestasi belajar penting sekali artinya guna membantu mahasiswa dalam mencapai prestasi belajar sebaik - baiknya.

\section{Hubungan Konsep Diri dengan Prestasi Belajar}

Prestasi belajar yang diperoleh merupakan hasil yang diperoleh melalui kegiatan sekolah dan umumnya bersifat kognitif, prestasi ini berhubungan dengan motivasi yang dimiliki seseorang. semakin baik konsep dirinya semakin tinggi motivasinya sehingga prestasi belajar semakin baik (Prabawati Setyo Pambudi, 2012).

\section{Hubungan Harga Diri dengan Prestasi Belajar}

Harga diri tinggi dapat membangkitkan rasa percaya diri, penghargaan diri, yakin akan kemampuannya merasa berguna (P. Yusi Riskayustiana, 2008), evaluasi terhadap diri akan mengasilkan perasaan berharga, mengenal potensi dirinya sehingga membentuk manusia memiliki kualitas sehingga mendorong mencapai prestasi yang tinggi (Dinda Ayu Noviariandani, 2012).

\section{Hubungan Konsep Diri dan Harga Diri dengan Prestasi Belajar}

Mahasiswa yang memilki konsep diri dan harga diri yang tinggi akan lebih aktif dalam belajar, rasa ingin tahu tinggi, lebih percaya diri, pikiran lebih terbuka sehinga lebih muda menerima pelajaran (Hastuti, 2009). Akan sangat berbeda bila mahasiswa yang memiliki harga diri rendah prestasi belajar kurang berhasil (Surani, 2013). Prestasi belajar dapat diraih oleh mereka yang memiliki antusias, motivasi, percaya diri dan tanggung jawab dan ciri banyak dimiliki mereka yang memiliki konsep diri positif dan harga diri tinggi (Pramesti, 2015).

\section{Metodologi Penelitian}

Penelitian ini dilaksanakan di Akes Rustida Prodi DIII Keperawatan Krikilan Glenmore Banyuwangi. Waktu penelitian pada bulan Februari sampai Agustus 2018. Jenis penelitian ini adalah deskriptif kuantitatif non eksperimental. Penelitian ini menggunakan metode deskriptif cross sectional dengan tujuan untuk mengetahui hubungan tipe kepribadian introvert dan ekstrovert dengan speaking skill pada mahasiswa semester II Akes Rustida Prodi DIII Keperawatan Tahun Ajaran 2017/2018. Menurut Sugiyono, (2009) populasi merupakan 
"wilayah generalisasi yang terdiri atas objek atau subjek yang mempunyai kuantitas dan karakteristik tertentu yang ditetapkan oleh peneliti untuk dipelajari dan kemudian ditarik kesimpulannya". Populasi penelitian ini adalah seluruh mahasiswa semester II Prodi DIII Keperawatan Tahun Ajaran 2017-2018. Teknik pengambilan sampel dari populasi penelitian ini menggunakan stratified simple random sampling sehingga didapatkan 45 subyek.

Variabel penelitian ini dioperasionalisasikan sebagai berikut variabel bebas (X1) adalah konsep diri, variabel bebas (X2) adalah harga diri, variabel terikat $(\mathrm{Y})$ adalah prestasi belajar mata ajar Bahasa Inggris.

Data diperoleh dengan menggunakan kuesioner. Penentuan skor untuk konsep diri dengan kategori skor baik sekali jika perolehan nilai >207 dikategorikan sangat tinggi, 173-206 tinggi, 139-172 sedang, 105-138 rendah, $5<105$ sangat rendah. Nilai harga diri tinggi jika $>75$, sedang $>51-75$, rendah 26-50, sangat rendah 1-25. Untuk mengetahui prestasi belajar mahasiswa, peneliti mengambil data melalui nilai akhir Bahasa Inggris mahasiswa di akhir pembelajaran semester genap Tahun Ajaran 2017-2018.

Analisis data merupakan bagian akhir sebelum membuat kesimpulan. Penelitian ini menganalisis data menggunakan tehnik statistik, dengan tujuan memperoleh gambaran selama penelitian. Penelitian ini menggunakan teknik analisis regresi linier berganda untuk mengukur kekuatan hubungan antara tiga variabel yang menunjukkan arah hubungan antara variabel bebas dan variabel terikat. Kemudian untuk menunjukkan apakah variabel bebas mempunyai pengaruh terhadap variabel terikat dan seberapa besar pengaruh kedua variabel bebas terhadap vaiabel terikat yang dianalisis dengan bantuan SPSS 22.00 (Riwidikdo, 2009).

Analisis konsep diri dalam penelitian ini menggunakan skala konsep diri menggunakan TSCS (Tennesee Self Concept Scale) William Fith yang kemudian dikembang oleh Sri Rahayu tahun 1979 yang terdiri dari 100 item pertanyaan dengan Cronbach's alpha 94\% (Anissa Devy Anggraini, 2016). Jawaban sangat sesuai (SS) 5, sesuai (S) 4, tidak pasti (TP) 3, tidak sesuai TS (2), sangat tidak sesuai STS (1). Harga diri diukur dengan menggunakan skala likert merupakan 
skala psikologis sikap yang dikembangkan oleh Rensis Likert 1932 yang terdiri dari 22 pertanyaan (Naike, 2017). Item jawaban selalu (SL) 5, sering (SR) 4, Kadang (K) 3, jarang (2), tidak pernah TP (1). Prestasi belajar mengacu pada nilai akhir dalam KHS yang diperoleh dalam kurun waktu satu semester dalam rentang skala rasio.

Uji analisis untuk mengetahui hubungan konsep diri dan harga diri dengan prestasi belajar dengan menggunakan product moment. Sedangkan untuk mengethaui korelasi konsep diri dengan harga terhadap prestasi belajar menggunakan analisi regresi linier berganda.

\section{Hasil dan Pembahasan}

\section{Hasil Penelitian}

Subyek penelitian ini adalah mahasiswa semester II Prodi D III Keperawatan sebanyak 45 subyek. Pada tabel berikut disajikan data karakteristik subyek berdasarkan jenis kelamin.

Tabel 1.Distribusi frekuensi responden mahasiswa semester II Prodi D III Keperawatan Tahun Ajaran 2017/ 2018.

\begin{tabular}{lcc}
\hline \multicolumn{1}{c}{ Jenis kelamin } & Frekuensi & Prosentase \\
\hline Laki-laki & 8 & $18 \%$ \\
Perempuan & 37 & $82 \%$ \\
\hline
\end{tabular}

Tabel di atas dapat disimpulkan bahwa distribusi frekuensi responden mahasiswa tingkat I semester II Prodi D III Keperawatan Tahun Ajaran 2017/2018 laki laki sebanyak 8 (18\%), sedangkan mahasiswa perempuan sebanyak $37(82 \%)$.

Tabel 2. Analisis frekuensi konsep diri mahasiswa semester II Prodi D III Keperawatan Tahun Akademik 2017/ 2018.

\begin{tabular}{lcc}
\hline Konsep diri & Frekuensi & Prosentase \\
\hline Sangat tinggi & 8 & 18 \\
Tinggi & 12 & 27 \\
Sedang & 15 & 33 \\
Rendah & 10 & 22 \\
Jumlah & 45 & $100 \%$ \\
\hline
\end{tabular}


Tabel 2 di atas memberikan gambaran bahwa konsep diri responden mahasiswa tingkat I semester II Prodi D III Keperawatan Tahun Ajaran 2017/2018 paling tinggi pada tingkat sedang sebanyak 15 responden (33\%).

Tabel 3. Analisis frekuensi harga diri mahasiswa semester II Prodi D III Keperawatan Tahun Akademik 2017/ 2018.

\begin{tabular}{lcc}
\hline Harga diri & Frekuensi & Prosentase \\
\hline Tinggi & 10 & 22 \\
Sedang & 20 & 44 \\
Rendah & 15 & 34 \\
Jumlah & 45 & $100 \%$ \\
\hline
\end{tabular}

Tabel 3 di atas memberikan gambaran bahwa harga diri pada responden mahasiswa tingkat I semester II Prodi D III Keperawatan Tahun Ajaran 2017/2018 paling tinggi berada pada tingkat sedang 20 responden (44\%).

Besar perhitungan korelasi antara variabel konsep diri dengan prestasi belajar pada mahasiswa tingkat I semester II Prodi DIII Keperawatan Tahun Ajaran 2017/2018 dengan koefisien korelasi konsep diri 0.040 dan $p<0,05$. Hasil ini menggambarkan adanya hubungan signifikan antara konsep diri dengan prestasi belajar. Besar perhitungan korelasi antara variabel harga diri dengan prestasi belajar pada mahasiswa tingkat I semester II Prodi DIII Keperawatan TA 2017/2018 yaitu didapatkan koefisien korelasi harga diri 0.890 dan $p>0,05$. Maka dapat disimpulkan, bahwa tidak terdapat hubungan yang signifikan antara harga diri dengan prestasi belajar.

Hasil analisis didapatkan adjusted $\mathrm{R}$ square $=0.094$. Hal ini menunjukkan bahwa pengaruh konsep diri dan harga diri terhadap prestasi belajar sebesar $9.4 \%$ sedangkan yang $90.6 \%$ prestasi belajar dipengaruhi oleh faktor lain. Hasil uji koefisien konsep diri nilai signifikansi $0.040>0.05$ dan harga diri 0.890>0.05. Namun nilai t konsep diri 2.124 dan harga diri 0.139. Maka dapat disimpulkan bahwa konsep diri lebih berpengaruh dari pada harga diri terhadap prestsi belajar. Adapun rumus regresi linier yang dibentuk adalah $\mathrm{Y}=42.739+0.130 \mathrm{X}_{1}+0.018$ $\mathrm{X}_{2}$. Persamaan regresi linier mengandung arti bahwa koefisien regresi konsep diri bernilai positif artinya pada saat hasil belajar, artinya bila mana konsep diri meningkat maka hasil belajar juga meningkat, dan bila konsep diri menurun hasil belajar juga menurun. Kenaikan konsep diri sebesar 1 poin akan meningkatkan 
hasil belajar sebesar 13 poin dan sebaliknya, penurunan konsep diri satu poin juga akan menurunkan hasil belajar sebesar 13 poin. Koefisien regresi harga diri bernilai positif memiliki arti yang sama dengan koefisien regresi konsep diri. Pada saat skor harga diri menguat maka hasil belajar akan mengalami peningkatan 18 poin. Begitu pula pada saat harga diri melemah terhadap hasil belajar sebesar 18 poin.

\section{Pembahasan}

Dalam sebuah penelitian memungkinkan judul suatu penelitian sama namun hasilnya bisa jadi berbeda atau bahkan sama dengan penelitian sebelumnya hal ini dapat dipengaruhi oleh perbedaan subyek yang dijadikan obyek dalam penelitian. Termasuk hasil penelitian yang akan dibahas dalam penelitian ini.

\section{Hubungan Konsep Diri terhadap Prestasi Belajar}

Berdasarkan hasil uji hipotesis yang berbunyi ada hubungan yang signifikan antara konsep diri terhadap prestasi belajar mata ajar Bahasa Inggris mahasiswa tingkat I semester II Prodi D III Keperawatan Tahun Ajaran 2017/2018 dapat dibuktikan kebenarannya. Analisis menggunakan teknik analisis regresi dua prediktor pada konsep diri dengan koefisien korelasi $0.040<0,05$. Hasil penelitian ini sama dengan penelitian terdahulu bahwa konsep diri yang baik berpengaruh terhadap prestasi belajar yang baik demikian juga sebaliknya (Prabawati Setyo Pambudi, 2012).

Konsep diri merupakan gambaran kepercayaan individu akan dirinya (Asy \& Assa, 2014), konsep diri positif merupakan pengakuan akan kualitas dirinya, (Prabawati Setyo Pambudi, 2012) mahasiswa yang memiliki konsep diri positif akan memiliki emosi positif dan motivasi belajar yang kuat (Handayani, 2012), tentu hal ini akan berpengaruh pada prestasi belajar (Saputri, 2016). Pendapat yang sama juga disampaikan oleh Handayani (2012) bahwa konsep diri positif dapat mengarahkan kepada gerak dan arah tujuan dalam belajar sehingga pencapaian prestasi belajar akan baik. Liauwrencia, (2014) mengatakan bahwa konsep diri positif dapat mempengaruhi prestasi belajar, demikian juga bila konsep diri negatif prestasi belajar dapat lebih rendah dari konsep diri positif. Konsep diri positif merupakan sesuatu yang penting dimiliki oleh setiap pelajar, 
dengan konsep diri yang baik dapat meningkatkan motivasi dalam belajar (Efendi, Asep Lukman, Muswardi Rosra, 2013). Dukungan sosial sangat dibutuhkan guna meningkatkan kepercayaan diri setiap mahasiswa sehingga mampu mengembangkan konsep diri dan memiliki kepercayaan diri yang penting bagi masa depannya (Woro Kusrini, 2014).

\section{Hubungan Harga Diri dengan Prestasi Belajar}

Berdasarkan hasil uji hipotesis yang berbunyi tidak terdapat hubungan antara harga diri dengan prestasi belajar mata ajar Bahasa Inggris mahasiswa tingkat I semester II Prodi D III Keperawatan Tahun Ajaran 2017/2018 dapat dibuktikan kebenarannya. Hasil uji statistik koefisien korelasi harga diri 0.890 dan $p>0,05$. Kesimpulan harga diri berpengaruh terhadap prestasi belajar hanya $89 \%$ dan yang $11 \%$ dipengaruhi faktor lain.

Hasil penelitian sama dengan penelitian terdahulu bahwa harga diri tidak berpengaruh pada prestasi belajar (Margono, 2014). Proses belajar merupakan suatu upaya individu mengenal lingkungan serta dapat menyesuaikan diri dengan lingkungan, di dalam proses belajar akan ada prestasi belajar yaitu perolehan nilai hasil belajar (Naike, 2017). Dalam penelitian lain disebutkan bahwa harga diri dapat berpengaruh terhadap prestasi belajar, namun juga terdapat hasil penelitian yang menyatakan bahwa harga diri tidak dapat mempengaruhi hasil belajar, hal ini dikarenakan prestasi belajar dipengaruhi oleh banyak faktor diantaranya: 1) stimulus belajar misalnya materi belajar, penugasan, dan suasana dalam belajar, 2) metode belajar yang digunakan untuk mengajar seperti proses belajar praktik, overlearning dan drill, penggunaan modalitas indra serta bimbingan dari pengajar, 3) faktor dari dalam individu termasuk kematangan, umur, jenis kelamin, pengalaman sebelumnya, kondisi kesehatan serta motivasi yang dimiliki oleh mahasiswa dalam belajar (Naike, 2017). Meskipun harga diri kurang berpengaruh pada prestasi hasil belajar pada mahasiswa Akes Rustida tingkat I semester II namun dukungan untuk memberi penguatan agar mahasiswa memiliki harga diri yang baik harus selalu dilakukan. Dengan harga diri yang baik mahasiswa akan memiliki kepribadian yang semakin matang dan timbul rasa percaya diri sehingga dapat menghasilkan prestasi belajar yang lebih baik (Persada, 2009). 


\section{Hubungan Konsep Diri dan Harga Diri dengan Prestasi Belajar}

Hasil analisis didapatkan Adjusted $\mathrm{R}$ square $=0.094$. Hal ini menunjukkan bahwa pengaruh konsep diri dan harga diri terhadap pretasi belajar sebesar sebesar $9.4 \%$ sedangkan yang $90.6 \%$ prestasi belajar dipengaruhi oleh faktor lain. Konsep diri merupakan suatu gambaran indivividu tentang sifat dan potensi diri (Prabawati Setyo Pambudi, 2012), isi pikiran, perasaanya dan bagaimana ia harus berperilaku terhadap orang lain (Prabawati Setyo Pambudi, 2012), sedangkan harga diri merupakan suatu evaluasi individu atas hasil yang telah dicapai (Persada, 2009). Evaluasi baik positif atau negatif yang berpengaruh pada ideal diri (Neny Irawwati, 2012). Konsep diri dan harga diri merupakan suatu kesatuan yang penting dalam diri individu, bila konsep diri baik maka harga diri juga akan baik demikian juga sebaliknya. Interaksi yang baik antara konsep diri dan harga diri dapat berpengaruh pada prestasi belajar, dan prestasi belajar dapat pula berpengaruh pada konsep diri positif dan harga diri yang tinggi. Dalam penelitian ini pengaruh konsep diri dan harga diri terhadap prestasi hanya belajar 9.4 \% pada mahasiswa Akes Rustida Prodi DIII Keperawatan Tahun Ajaran 2017/2018. Hasil tersebut memberikan gambaran bahwa prestasi belajar tidak semata-mata hanya dipengaruhi hal konsep diri dan harga diri akan tetapi ada faktor lain. Adapun faktor yang mempengaruhi hasil belajar adalah 1) kemampuan bawaan, 2) kepribadian, 3) kondisi fisik, 4) fasilitas dan alat belajar, 5) perhatian dan dukungan orang tua, 6) dan motivasi (Persada, 2009). Hasil penelitian ini memberikan gambaran serta evaluasi bagi pengajar bahwa perlu melakukan perubahan dan strategi pembelajaran bagi mahasiswa agar tercapai prestasi belajar yang lebih baik.

\section{Kesimpulan dan Saran}

\section{Kesimpulan}

1. Terdapat hubungan antara konsep diri dengan prestasi belajar mata ajar Bahasa Inggris mahasiswa semester II Prodi D III Keperawatan Tahun Ajaran 
$2017 / 2018$.

2. Tidak terdapat hubungan antara harga diri dengan prestasi belajar mata ajar Bahasa Inggris mahasiswa semester II Prodi D III Keperawatan Tahun Ajaran $2017 / 2018$.

3. Terdapat hubungan antara konsep diri dan harga diri dengan prestasi belajar mata ajar Bahasa Inggris mahasiswa semester II Prodi DIII Keperawatan Tahun Ajaran 2017/2018.

\section{Saran}

1. Institusi pendidikan tempat penelitian dilaksanakan hendaknya menambah fasilitas belajar mengajar Bahasa Inggris, seperti pengadaan laboratorium Bahasa Inggris yang sesuai standar untuk jenjang pendidikan setara dengan universitas.

2. Institusi pendidikan tempat penelitian dilaksanakan hendak-nya menyediakan literatur Bahasa Inggris yang beragam dan up date sebagai bahan rujukan mahasiswa.

3. Dosen pengampu mata kuliah Bahasa Inggris hendaknya memiliki inovasi dalam pelaksanaan pembelajaran agar mahasiswa tidak bosan dalam mengikuti pembelajaran.

\section{DAFTAR PUSTAKA}

Abu Ahmadi dan Widodo Supriyanto. 2004. Psikologi belajar. Jakarta: Rineka Cipta.

Anissa Devy Anggraini. (2016). Konsep diri mahasiswa. Universitas Sanata Dharma Yogyakarta.

Asy, M., \& Assa, S. M. K. (2014). Konsep Diri , Kecerdasan Emosi Dan Motivasi Belajar Siswa. Jurnal Psikologi Indonesia, 3(1), 83-89.

Budiawan. (2008). Pengaruh Sikap Bahasa dan Motivasi Belajar Bahasa terhadap Prestasi pada Mata Pelajaran Bahasa Indonesia dan Bahasa Inggris Siswa SMA se-Bandar Lampung. Universitas Indonesia.

Dinda Ayu Noviariandani, M. L. (2012). Harga diri, efikasi diri, motivasi belajar dan prestasi akademik siswa SMA pada berbagai model pembelajaran. Jurnal Ilmu. Kel \& Kons, 5(2). 
Efendi, Asep Lukman, Muswardi Rosra, Y. (2013). Hubungan antara konsep diri dalam belajar dan motivasi belajar dengan prestasi belajar akademik mahasiswa. Universitas Lampung.

Handayani, A. (2012). Hubungan Antara Konsep Diri Dan Kematangan Emosi Dengan Penyesuaian Diri Istri Yang Tinggal Bersama Keluarga Suami. Jurnal Psikologi Pitutur, 1(1).

Hastuti, D. P. (2009). Hubungan konsep diri dan kecerdasan emosi dengan prestasi belajar siswa akutansi kelas XI SMK Perguruan Rakyat Jakarta 2008/2009. Niversitas Sebelas Maret Surakarta.

Hermayawati. (2010). Analisis kesulitan belajar bahasa inggris mahsiswa. Jurnal Sosio-Humaniora, 1(1), 1-14.

Kamila, I. I. (2013). Perbedaan Harga Diri ( Self Esteem) Remaja Ditinjau dari Keberadaan Ayah. Jurnal Psikologi, 9(2).

Liauwrencia, P. F. (2014). Hubungan antara konsep diri dengan prestasi belajar siswa kelas XII IPA@2013/2014 SMA Dharma Putra Tangerang. Jurnal Noetic Psychology, 4(1), 62-80.

Margono, A. D. (2014). Hubungan Harga Diri dan Dukungan Teman Sebaya dengan Prestasi Belajar. UIN Sunan Ampel Surabaya.

Naike, S. B. (2017). Hubungan harga diri dengan prestasi belajar di kelas VIII SMPN 2 Batusangkar. IAIN Batusangkar.

Neny Irawwati, N. J. (2012). Hubungan antara harga diri dengan prestasi beajar pada siswa SMKN 48 Jakarta Timur. Econo Sains, X(2), 193-210.

P. Yusi Riskayustiana, S. \& I. (2008). Self esteem. Bandung, Indonesia.

Pambudi, P. S., \& Wijayanti, D. Y. (2011). Hubungan Konsep Diri dengan Prestasi Akademik pada Mahasiswa Keperawatan 1) Mahasiswa Program Studi Ilmu Keperawatan Fakultas Kedokteran 2 ) Staf pengajar Departemen Keperawatan Jiwa Program Studi Ilmu Pendahuluan Konsep diri adalah semua bentuk kepercay, 149-156.

Persada, S. H. (2009). Hubungan antara harga diri dengan prestasi belajar pada mahasiswa fakultas kedokteran Unmuh Surakarta 2007. Universitas Muhammadaiyah Surakarta. 
Prabawati Setyo Pambudi, D. Y. W. (2012). Hubungan konsep diri dengan prestasi akademik mahasiswa keperawatan. Jurnal Keperawatan Soedirman, 7(2), 93-99.

Pramesti, A. (2015). Hubungan antara self esteem terhadap pretasi belajar mata pelajaran makanan kontinental pada siswa jurusan tataboga konsentrasi boga SMKN 1 Sewon. UIN Yogyakarta.

Ratih, K. (2005). Motivasi dalam usaha meningkatkan ketrampilan wicara bahasa inggris mahasiswa jurusan non bahasa inggris Universitas Muhammadiyah Surakarta 2001/2002. Jurnal Penelitian Humaniora, 6(1), 14-27.

Risa Paskahandriati, I. K. (2010). HUbungan antara harga diri dan prestasi belajar fisika pada siswa STM. UNIVERSITAS sETIA bUDI sURAKARTA.

Riwidikdo, H. (2009). Statistik kesehatan. Yogyakarta: Rohima Press.

Rizal, S. (2013). Analisis kebutuhan bahan ajar bahasa inggris IAIN Bengkulu melalui students Need Analysis. Jurnal At-Ta'lim, 12(2), 232-252.

Saputri, A. N. (2016). Hubunga konsep diri engan hasil belajar IPS siswa kelas $V$ SDN kecamatan Bodeh Kabupaten Pemalang. Universitas Negeri Semarang.

Sugiyono. (2009). Statistik untuk penelitian. Bandung: Alfabeta.

Sumantri, B. (2011). Hubungan antara konsep diri dengan prestasi belajar pada mahasiswa pendidikan ekonomi STIKIP PGRI Ngawai. Jurnal Media Prestasi, VIII(2), 131-143.

Surani, M. (2013). Hubungan prestasi belajar dengan harga diri mahasiswa semester III PSIK Stikes Aisyiyah. STikes Aisyiyah Yogyakarta.

Sutiyoso. (2010). Peningkatan kemampuan berbahsa inggris mahasiswa seni tari semesert IV melalui KBM berbahasa inggris pada MK kajian dan penigatan pengembangan kurikulum dengan pendekatan cooperative learning. Universitas Negeri Yigyakarta.

Widiarti, A. W. (2007). Hubungan harga diri dan kreativitas dengan prestasi belajar mahasiswa semester I jurusan fisioterapi Poltks Surakarta. Poltekes Surakarta.

Woro Kusrini, N. P. (2014). Hubungan dukungan sosial dan kepercayaan diri dengan prestasi bahasa inggris siswa kelas VIII SPMN 6 Boyolali. Jurnal Penelitian Humaniora, 15(1), 131-140. 